\title{
The Effect of Risk Factors on Surgical and Oncological Results in High - Risk Prostate Cancer: A Multicenter Study of the Urooncology Society, Turkey
}

\author{
Volkan Izol ${ }^{1}$, Nebil Akdogan ${ }^{1}$, Haluk Ozen², Bulent Akdogan ${ }^{3}$, Ali Riza Kural ${ }^{4}$, Mustafa \\ Tuna $^{5}$, Sinan Sözen ${ }^{6}$, Levent Turkeri ${ }^{7}$, and Mustafa Tansug ${ }^{1}$ \\ ${ }^{1}$ Cukurova University Faculty of Medicine \\ ${ }^{2}$ Hacettepe University Faculty of Medicine \\ ${ }^{3}$ Hacettepe University \\ ${ }^{4}$ Acibadem Maslak Hastanesi \\ ${ }^{5}$ Acibadem Saglik Grubu \\ ${ }^{6}$ Gazi University \\ ${ }^{7}$ Acibadem University
}

January 31, 2021

\begin{abstract}
Purpose To evaluate the effect of risk factors and selected surgical methods on operative and oncological results of patients undergoing radical prostatectomy (RP) with high-risk prostate cancer (HRPC). Methods Retrospective analysis of patients, who underwent RP for HRPC from 13 urology centers between 1990 to 2019, was performed. Groups were created according to the risk factors of D'Amico classification. Patients with one risk factor were included in group 1 where group 2 consisted of patients with two or three risk factors. Results A total of 1519 patients were included in this study and 1073 (70.6\%) patients assigned to group 1 and $446(29.4 \%)$ patients to group 2. Overall (biochemical and/or clinical and/or radiological) progression rate was $12.4 \%$ in group 1 and $26.5 \%$ in group $2(\mathrm{p}=0.001)$. Surgical procedure was open RP in $844(55.6 \%)$ patients and minimally invasive RP in 675 (44.4\%) patients (laparoscopic and robot-assisted RP in $230(15.1 \%)$ and $445(29.3 \%)$ patients, respectively). Progression rates were similar in different types of operations $(\mathrm{p}=0.22)$. Progression rate was not significantly different in patients who either underwent pelvic lymph node dissection (PLND) or not in each respective group. Conclusion $\mathrm{RP}$ alone is an effective treatment in the majority of patients with HRPC and PLND did not affect the progression rates after RP. According to the number of preoperative high-risk features, as the number of risk factors increases, there is a need for additional treatment.
\end{abstract}

\section{Hosted file}

manuscript.pdf available at https://authorea.com/users/339530/articles/506592-the-effectof-risk-factors-on-surgical-and-oncological-results-in-high-risk-prostate-cancer-amulticenter-study-of-the-urooncology-society-turkey

\section{Hosted file}

Table 1.pdf available at https://authorea.com/users/339530/articles/506592-the-effectof-risk-factors-on-surgical-and-oncological-results-in-high-risk-prostate-cancer-amulticenter-study-of-the-urooncology-society-turkey

\section{Hosted file}


Table 2.pdf available at https://authorea.com/users/339530/articles/506592-the-effectof-risk-factors-on-surgical-and-oncological-results-in-high-risk-prostate-cancer-amulticenter-study-of-the-urooncology-society-turkey

\section{Hosted file}

Table 3.pdf available at https://authorea.com/users/339530/articles/506592-the-effectof-risk-factors-on-surgical-and-oncological-results-in-high-risk-prostate-cancer-amulticenter-study-of-the-urooncology-society-turkey

\section{Hosted file}

Table 4.pdf available at https://authorea.com/users/339530/articles/506592-the-effectof-risk-factors-on-surgical-and-oncological-results-in-high-risk-prostate-cancer-amulticenter-study-of-the-urooncology-society-turkey

\section{Hosted file}

Table 5.pdf available at https://authorea.com/users/339530/articles/506592-the-effectof-risk-factors-on-surgical-and-oncological-results-in-high-risk-prostate-cancer-amulticenter-study-of-the-urooncology-society-turkey

\section{Hosted file}

Figure 1.pdf available at https://authorea.com/users/339530/articles/506592-the-effectof-risk-factors-on-surgical-and-oncological-results-in-high-risk-prostate-cancer-amulticenter-study-of-the-urooncology-society-turkey 